\title{
STUDY OF THE BIOTRANSFORMATION OF BENFLURON USING THE ISOLATED PERFUSED RAT LIVER
}

\author{
Zbyněk Svoboda ${ }^{1}$, Milan Nobilis ${ }^{1}$, Jaroslav Květina ${ }^{1}$, Karel Lemr ${ }^{2}$ \\ Institute of Experimental Biopharmaceutics, Joint Research Centre of PRO.MED.CS Praha a.s. and the Czech Academy \\ of Sciences, Hradec Králové ${ }^{1}$; Palacky University, Olomouc: Department of Analytical Chemistry²
}

\begin{abstract}
Summary: The isolated perfused rat liver method (IPRL) was used to find, isolate and identify further metabolites of Phase I and Phase II biotransformation of the potential cytostatic agent benfluron with special regard to the conjugation processes. Its pharmacokinetic profile during the perfusion was also estimated. The rat liver was isolated from the body and perfused in vitro using a recirculating perfusion system. Benfluron was added to the reservoir as a bolus in doses of 200, $100,30 \mathrm{mg} / \mathrm{kg}$ of body weigh and $1 \mathrm{mg} /$ perfusate volume and also as a continual infusion in a dose of $0.1 \mathrm{mg} / \mathrm{min}$ in separate series of experiments. The following metabolites formed during Phase I biotransformation were found in the perfusion liquid as well as in the bile: benfluron N-oxide, 9-hydroxy benfluron, demethylated 9-hydroxy benfluron, demethylated benfluron, and reduced benfluron. The major Phase II metabolite found in the bile samples was the glucuronide of 9-hydroxy benfluron. The pharmacokinetic profile of benfluron in IPRL indicated its main disposition and metabolic pathway, i.e. its rapid extraction from perfusate by the liver $\left(\mathrm{t}_{1 / 2 \alpha}=3.76 \mathrm{~min}\right)$, 9-hydroxylation followed up O-glucuronidation and excretion to the bile. It was revealed that $12 \%$ of the total dose of the parent compound was excreted to the bile in the form of conjugates during the first hour of perfusion, $32 \%$ during 1.5 hour, and $70 \%$ during 2 hours after the administration of benfluron. The conjugates with glucuronic acid represented $96-98 \%$ of all metabolites found in the bile.
\end{abstract}

Key words: Isolated perfused rat liver; Benfluron biotransformation; O-glucuronide conjugation

\section{Introduction}

Benfluron [5-(2-dimethylaminoethoxy)-7-oxo-7H-ben$\mathrm{zo}$ [c]fluorene hydrochloride] is a potential antineoplastic agent $(5,6)$ exhibiting interesting pharmacodynamic properties in experiments carried out in vitro (in animal and human cells) and in vivo $(2,9,10,11)$. Biotransformation of benfluron was also studied with the use of experimental in vivo and in vitro methods. A number of metabolites generated during Phase I biotransformation have been detected (see Fig. 1) (4,13). A high-performance liquid chromatographic method was developed to determine benfluron and its metabolites in extracts from biological samples (7). However, previous studies on benfluron biotransformation revealed significant differences in recovery measurements, i.e. a difference in the total amount of benfluron given to the rat and the sum of the nine metabolites found in faeces and in urine over eleven days after oral administration of the parent compound. Oral administration of benfluron has been shown to lead to very poor absorption due to strong affinity of this compound to the rat stomach wall $(1,14)$. The second possibility of how to explain the disproportion of recovery in the previous experiment is that benfluron may form metabolites and their derivatives which are poorly extracted and/or are hardly detectable because of their changed structure and polarity (e.g. polar metabolites or conjugates formed during Phase II biotransformation).

The aim of the present study was to find, isolate and identify further metabolites of Phase I and to evaluate, mainly, Phase II biotransformation of benfluron using the isolated perfused rat liver (IPRL). The pharmacokinetic profiles of benfluron and its metabolites during the perfusion were also estimated.

\section{Material and Methods}

\section{Chemicals}

Sodium chloride, potassium chloride, calcium chloride, potassium dihydrogen phosphate, magnesium sulfate, sodium hydrogen carbonate, glucose, and polyvinylpyrolidone K 25 (all of analytical grade, Fluka) were used to prepare Krebs-Henseleit bicarbonate buffer (8) used in the isolated perfused liver.

Acetonitrile (HPLC grade, Merck), nonylamine (purum, Fluka), chloroform, methanol, 2-propanol, phosphoric acid $(85 \%)$, aqueous ammonia $(26 \%)$, triethylamine, 
<smiles>CC[C@H]1c2cc(O)ccc2-c2c1cc(OCCN(C)C)c1ccccc21</smiles><smiles>CNCCOc1cc2c(c3ccccc13)-c1c(O)cccc1C2</smiles><smiles>CNCCOc1cc2c(c3ccccc13)-c1ccccc1C2O</smiles><smiles>CCCN(C)CCOc1cc(OCCN(C)CC)c2c(c1)C(=O)c1ccccc1-2</smiles><smiles>CCN(C)CCOc1cc(OC)c2c(c1)C(O)c1ccccc1-2</smiles><smiles>O=C1c2cc(O)ccc2-c2c1cc(O)c1ccccc21</smiles><smiles>CCC[N+](C)(O)CCOc1cc2oc3ccccc3c2c2ccccc12</smiles>

8<smiles>[CH2]C=CC=CC</smiles><smiles>Cc1c(OCCN(C)C)cc2c(c1C)-c1ccccc1C2O</smiles><smiles>CC(C)(O)C1CCCCC1</smiles><smiles>CN(C)CCOc1cc2c(c3ccccc13)-c1ccccc1C2O</smiles><smiles>Oc1ccc2c(c1)C(O)c1cc(O)c3ccccc3c1-2</smiles>

Fig. 1: Chemical structures of benfluron (compound No. 10) and its metabolites with their hypothetical pathways.

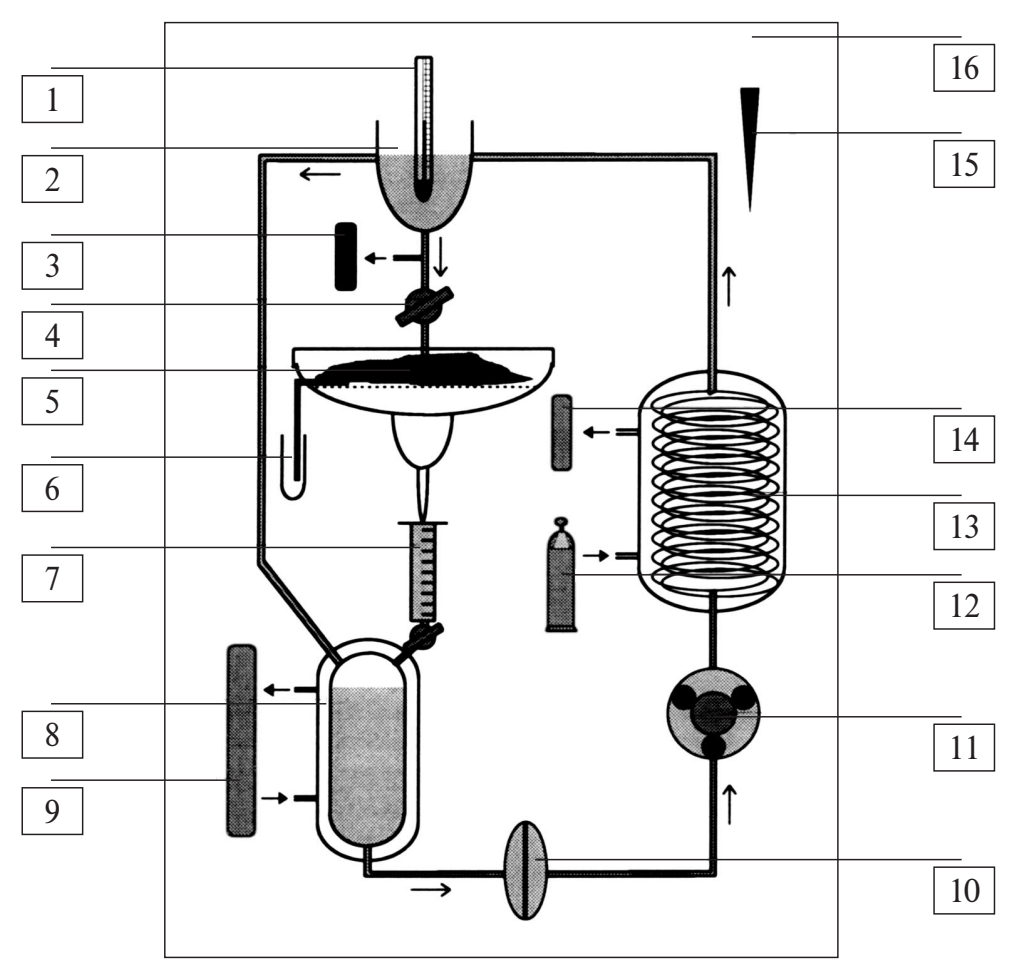

Fig. 2: Diagram of a recirculating liver perfusion apparatus:

1. thermometer;

2. constant head device;

3. electromanometer;

4. three-way stopcock;

5. liver platform with organ;

6. vial to collect bile;

7. flow meter;

8. thermostatically controlled reservoir;

9. thermostat;

10. filter;

11. peristaltic pump;

12. pneumoxide;

13. oxygenator;

14. manometer;

15. thermostatic control unit;

16. constant temperature cabinet. 
and ethyl acetate (all of analytical grade, Lachema) were used for sample preparation, thin-layer chromatography (TLC) and high-performance liquid chromatography (HPLC).

Nonylamine buffer for the mobile phase and five benzo[c]fluorenes standard mixtures (compounds 4, 7, 8, 9 and 10, synthesis: M. Nobilis) were used for HPLC assay.

\section{Laboratory animals}

Male rats Wistar Han II (Rattus norvegius var. alba, conventional breeding facility of the Research Institute for Pharmacy and Biochemistry, Konárovice nad Labem, Czech Republic; 250-300 g) were used. They were fasted overnight and were allowed free access to water before the experiment. The experiments were approved by the local ethics committee.

\section{Liver Perfusion}

The rat liver was perfused in vitro using a modified surgical and perfusion technique described previously (8). Animals were anaesthetized with pentobarbital $(60 \mathrm{mg} / \mathrm{kg})$ before surgery. Freshly prepared and filtered albumin- and erythrocytes-free Krebs-Henseleit bicarbonate buffer ( $\mathrm{pH}$ $7.4)$, supplemented with glucose $(0.1 \%)$, polyvinylpyrrolidone $(3.5 \%)$ as the plasma expander, and heparin (6.7 i.u./ml) and bubbled with humidified mixture of $95 \% \mathrm{CO}_{2}$ and $5 \% \mathrm{O}_{2}$, was delivered to the portal vein catheter. A flow rate of about $4 \mathrm{ml} / \mathrm{g}$ liver/min was maintained. The temperature of the perfusion cabinet and perfusion medium was thermostatically controlled at $37 \pm 0.5^{\circ} \mathrm{C}$. Perfusion was conducted using the recirculating mode. Cannulation of the common bile duct permitted collection of bile, the flow rate of which was determined gravimetrically. An initial stabilization period of $30 \mathrm{~min}$ was allowed before adding benfluron to the perfusion medium.

The perfusate flow rate, bile production and organ appearance were determined during the perfusion, organ weigh and organ histopathology were determined after the perfusion to evaluate liver viability. The IPRL method was also previously established according to organ oxygen consumption using a Clarke-Type oxygen electrode (Lazar Research Institute, USA).

In the first series of experiments, IPRL preparations were perfused with different bolus doses of benfluron: 200, 100 and $30 \mathrm{mg} / \mathrm{kg}(\mathrm{n}=2$ for each dose $)$ and $1 \mathrm{mg} /$ perfusate volume $(n=4)$. These experiments were performed to define the metabolic profile of benfluron and to assess its various metabolites in the perfusate and bile. Perfusate and bile samples were collected at 15-min intervals after the addition of benfluron.

Additional two IPRL experiments were conducted in which the livers were perfused with constant infusion rate of benfluron $(0.1 \mathrm{mg} / \mathrm{min})$ to produce a sufficient quantity of conjugates for their further identification. Bile samples were collected at 10-min intervals during $120 \mathrm{~min}$ of perfusion.

\section{Sample preparation}

The samples of perfusion liquid were alkalized with the same volume of $15 \%$ aqueous ammonia to $\mathrm{pH}$ 9-10 and repeatedly extracted (three times) with $10 \mathrm{ml}$ of ethyl acetate. Ethyl acetate extracts were evaporated in vacuo (max. $40^{\circ} \mathrm{C}$ ) to dryness. The residues were dissolved in a known volume (usually $1-2 \mathrm{ml}$ ) of the mobile phase, to be used in HPLC. The collected bile was only diluted with the mobile phase used in HPLC or in methanol for preparative TLC.

\section{Chromatography}

A Thermo Separation Products chromatograph setup was used. An HPLC column LiChroCART 125 x 4 mm with a precolumn LiChrospher 100 RP-18 (Merck) were used. The samples were assayed using a Spectra FOCUS high speed scanning UV detector. Detection was performed in dual wavelength mode ( 295 and $340 \mathrm{~nm}$ ) or in high-speed scanning mode (range 195-365 nm).

A preparative TLC was used for the isolation of the newly found metabolites and their conjugates in bile. For more details see the literature (12).

\section{Liquid Chromatography-Mass Spectrometry}

A Beckman System Gold setup (pump 125S, diode-array UV detector 168) and a Finnigan MAT setup (LCQ ion trap mass spectrometer coupled with a liquid chromatograph by an electrospray interface) were used for metabolites identification (LC/MS). It allowed to follow molecular masses of the compounds in the sample as well as to perform fragmentation of selected ions.

\section{Calculation}

A Table Curve 2D software (SPSS Inc., version 4) was used to calculate pharmacokinetic data $\left(\mathrm{t}_{1 / 2 \alpha}=\right.$ half-time associated with the rapid elimination phase, $t_{1 / 2 \beta}=$ halftime associated with the slow elimination phase) from mean perfusate and bile concentrations of benflurone and its metabolites. Bile excretion rate of metabolite was expressed as mean \pm standard deviation.

\section{Results}

All data presented in this chapter were obtained after administration of $1 \mathrm{mg}$ of benfluron into the IPRL system (see discussion). Using the IPRL method, the following metabolites of benfluron formed during Phase I biotransformation were found in the perfusion liquid as well as in the bile:

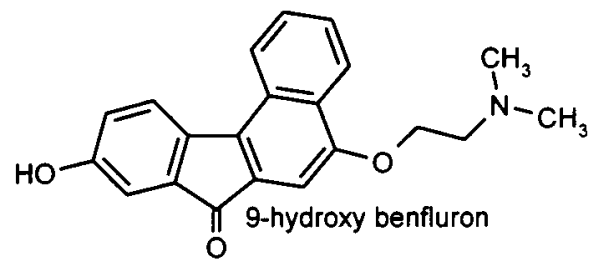


<smiles></smiles><smiles>CNCCOc1cc2c3ccccc3c(=O)c3cc(O)ccc3c2c2ccccc12</smiles><smiles>CON(C)c1cc(OCC[N+](C)(C)O)c2ccccc2c1-c1ccccc1</smiles><smiles>CN(C)CCOc1cc2c(c3ccccc13)-c1ccccc1C2O</smiles>

It revealed, in a short retention time of HPLC analyses, the main metabolite of benfluron, identified by LC/MS as the product of conjugation of 9-hydroxy benfluron with glucuronic acid formed during the Phase II biotransformation, i.e. O-glucuronide of 9-hydroxy benfluron.<smiles>CN(C)CCOc1cc2c(c3ccccc13)-c1ccc(OC3OC(C(=O)O)C4OC3[C@H](O)[C@H]4O)cc1C2=O</smiles>

O-glucuronide of 9-hydroxy benfluron

Kinetic disposition of benfluron in the IPRL system.

A two-compartment model was used to depict benfluron elimination from an isolated perfused liver preparation. The rate of disappearance of benfluron from the perfusate of such a system is described by the following biexponential equation:

$$
\mathrm{c}_{[\text {benfl. }] \mathrm{t}}=2757 \mathrm{e}^{-0.18425 . \mathrm{t}}+94 \mathrm{e}^{-0.01095 . \mathrm{t}}
$$

Evaluation of the pharmacokinetic parameters revealed the half-time of the rapid distribution phase of benfluron $t_{1 / 2 \alpha}=3.76$ min. The half-time of the elimination phase of benfluron was determined to be $t_{1 / 2 \beta}=63.30 \mathrm{~min}$. The course of elimination of benfluron from the perfusion medium in dependence on time is shown in Fig. 3. Graphic representation of excretion of the principal metabolite (glucuronide 9-hydroxy benfluron) into bile in dependence on time is shown in Fig. 4. The half-life of achieving its steady-state phase of excretion was estimated to be $10.40 \mathrm{~min}$.

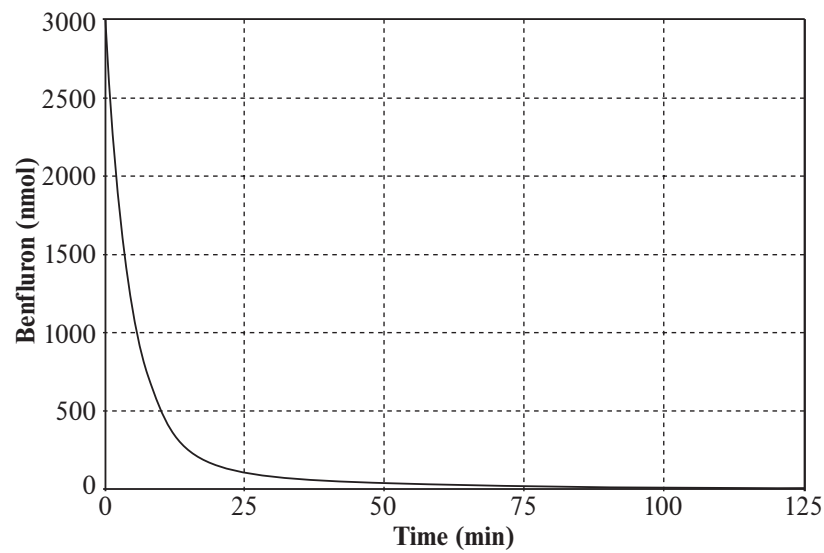

Fig. 3. The elimination kinetics of benfluron from the perfusate after administration of $1 \mathrm{mg}$ of benfluron into the IPRL system.

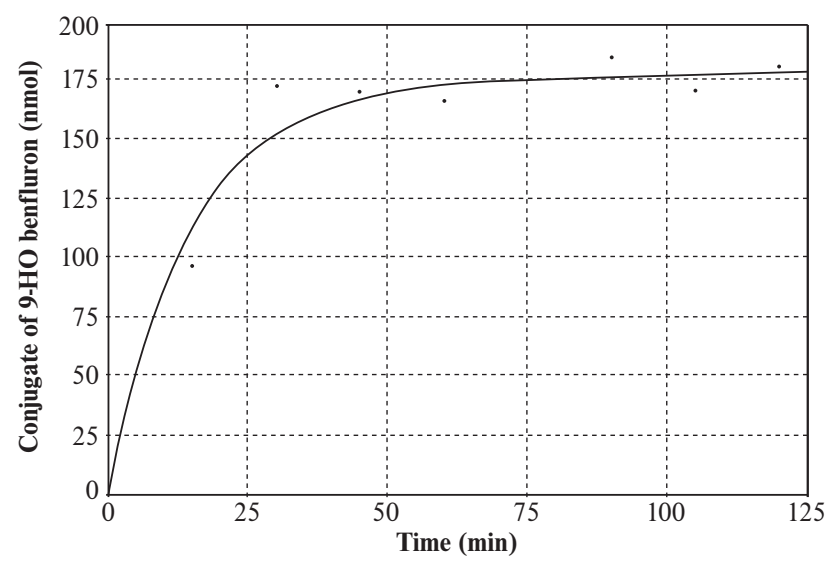

Fig. 4. The kinetics of biliary excretion of the principal metabolite of benfluron (conjugate of 9-hydroxy benfluron) after administration of $1 \mathrm{mg}$ of benfluron into the IPRL system.

Percentile share of the conjugates from the administered dose represented $70 \%$ of the total amount of excreted benfluron and its metabolites into bile after 2 hours of perfusion. For details see Tab. 1. 
Tab. 1: Percentile representations of the conjugates from the administered dose in bile in vitro in dependence on time.

\begin{tabular}{|c|c|}
\hline $\begin{array}{c}\text { Time of perfusion after } \\
\text { benfluron administration } \\
{[\mathrm{h}]}\end{array}$ & $\begin{array}{c}\text { Conjugates } \\
\text { [cumulative \% } \\
\text { from administered dose] }\end{array}$ \\
\hline 1 & $12 \pm 5$ \\
1.5 & $32 \pm 11$ \\
2 & $70 \pm 19$ \\
\hline
\end{tabular}

\section{Discussion}

The use of the IPRL method made it possible to find metabolites of Phase I and Phase II biotransformation of benfluron. The presented results clearly show that benfluron undergoes massive biotransformation in the liver compartment, above all hydroxylation in position 9 and subsequent conjugation with glucuronic acid.

It was not possible to implement the original intention of finding minority metabolites by saturating biotransformational pathways by using large doses of benfluron. The use of high benfluron concentrations in the IPRL system resulted in marked changes in the examined parameters of functional capacity of the isolated liver, i.e. a decrease in perfusate flow, a decrease in oxygen consumption, and failure of biliary excretion. For this reason the doses were gradually decreased from $200 \mathrm{mg} / \mathrm{kg}$ to $1 \mathrm{mg} /$ volume of perfusion medium. This dose did not result in the described changes and neither did continual infusion at a rate of 0.1 $\mathrm{mg} / \mathrm{min}$ which was employed to produce sufficient amounts of metabolites intended for their identification using the LC/MS method. Interpretation of the changes in the functional capacity of the liver preparation after administration of large doses of benfluron can be based on a recent paper by Kopecký F. and Kopecká B. (3), which solves the physico-chemical properties of benfluron in aqueous medium in dependence on the ionic strength of the solution. Benfluron hydrochloride is a substance relatively well soluble in aqueous media. However, it has been found that in the presence of potassium chloride (and other electrolytes $)$ in approximately osmotic concentrations $\left(c_{\mathrm{KCl}}=0.15\right.$ $\mathrm{mol} / \mathrm{l}$ ) benfluron produces ionic pairs and molecular associates without an outer electric charge, which results in microprecipitation of benfluron in the solution. These multimers, as substances with a relatively large molecular mass, could be the cause of the above-mentioned loss of the functional capacity of IPRL, as under these conditions the solubility of benfluron in aqueous medium rapidly decreases, which can result in an impairment of the microvascular system of the liver. Under these conditions the solubility of benfluron resembles that of the unprotonized benfluron base and it is therefore only $c_{\text {benfluron }}=1.1 \cdot 10^{-4} \mathrm{~mol} / 1$.
Recalculation of ion concentrations of employed KrebsHenseleit solution and the achieved concentrations of benfluron in perfusion medium $\left(c_{\text {benfluron }}=1.9 .10^{-5} \mathrm{~mol} / \mathrm{l}\right)$ has revealed that the used concentration of benfluron in a dose of $1 \mathrm{mg}$ /volume of perfusion medium lies just below the limit of the concentration region of the formation of the above-mentioned multimers.

An analysis of absorption spectra obtained by high-speed UV scanning detection revealed the products of Phase I biotransformation, i.e. demethylated 9-hydroxy benfluron and twice demethylated 9-hydroxy-benfluron, including other previously described metabolites (see Results). In detailed analysis of elution zones in the region of short retention times, the spectra characteristic of benzo[c]fluorene structures were found. For this reason the HPLC method was modified, which resulted in prolongation of elution times of metabolites and made possible to separate the found structures. Their isolation and identification using the LC/MS method have revealed that it is the product of conjugation of 9-hydroxy benfluron with glucuronic acid. In the regions of short retention times (HPLC), the method of mass spectrometry has revealed other masses of molecules, which could correspond to other conjugates (but their full identification has not been completed yet).

Conjugates excreted into bile in the course of 2 hours of perfusion represent $70 \%$ (Table 1) of the administered dose of the parent drug and 96-98\% of all metabolites found. It gives evidence for a large share of conjugation mechanisms in biotransformation of benfluron by the liver and suggests possible enterohepatic kinetics of benfluron in in vivo conditions. The construction of a probable scheme of benfluron biotransformation is shown in Fig. 1.

\section{Acknowledgement}

We thank prof. MUDr. Vladimír Herout, DrSc. for histopathological examinations.

\section{References}

1. Francová V, Šmolík S, Schlehrová M et al. Derivatives of benzo[c]fluorene XVI. Absorption, distribution and elimination of 3H-benfluorene, 5-[2-(N,N-dimethylamino)ethoxy]-7-oxo-7 $\mathrm{H}$-benzo[c]fluorene hydrochloride in rats after oral and intravenous administration. Neoplasma 1985:32:529-36.

2. Jantová S, Horáková K. 9-Hydroxybenfluron Induced Inhibition of Proliferation and Metabolism in HeLa Cells. Cell Biochem Funct 1993;11:131-5.

3. Kopecký F, Kopecká B. Basicity, ionic associations and their effect on solubility of the antioneoplastic benflurone. Chem Papers 1997;51:99-106.

4. Koruna I, Ryska M, Poláková L et al. Metabolity benfluronu in vivo. Cesk Farm 1986;35:451-5.

5. Křepelka J, Roubík J, Holoubek J, Vančurová I. 5-, 6- and 7-substitution derivatives of 7-oxo-7H-benzo $(c)$ fluorene. Coll Czechoslovak Chem Commun 1982;47:1258-66.

6. Křepelka J, Vančurová I, Holoubek J, Mělka M, Řežábek K. Derivatives of benzo[c]fluorene: II. Synthesis and biological effect of basic ethers of 7 -oxo-7 $H$-benzo[c]fluorene. Coll Czechoslov Chem Commun 1982;47:1856-66.

7. Kvasničková E, Nobilis M, Hais IM. Chromatographic characterization of in vitro metabolites of 5[2-(N,N-dimethylamino)ethoxy]-7-oxo-7H-benzo[ $c$ ]fluorene. J Chromatogr 1984;295:201-9.

8. Květina J, Guaitani A. A Versatile Method for the in vitro Perfusion of Isolated Organs of Rats and Mice with Particular Reference to Liver. Pharmacology 1969;2:65-81. 
9. Mělka M, Křepelka J. Benfluron hydrochloride. Drugs Future 1987;12:745-8.

10. Miko M, Křepelka J, Mělka M. 9-Hydroxybenfluron: cytostatic effects and inhibition of macromolecular biosynthesis in Ehrlich ascites and P388 murine leukemia cells. Anti-Cancer Drugs 1991;2:289-95.

11. Miko M, Křepelka J, Mělka M. Cytolytic activities of benfluron metabolites and loss of transplantability. Int J Tiss Reac 1989;XI:143-51.

12. Nobilis M, Anzenbacher P, Pastera $P$ et al. Study of the biotransformation of a potential benzo[c]fluorene antineoplastic using high-performance liquid chromatography with high-speed-scanning ultraviolet detection. J Chromatography B 1996;681:143-51

13. Nobilis M, Kvasničková E, Šroler A, Hais IM. Elimination of benflurone and it metabolites in the faeces and urine of rats. Drug Metab Drug Interact 1991;9:22540.

14. Roubal Z, Poláková L, Grimová J et al. Deriváty benzo(c)fluorenu. XVII Farmakokinetika Benfluronu u zviŕat. Cesk Farm 1985;34:311-3.

Mgr. Zbyněk Svoboda,

Institute of Experimental Biopharmaceutics, Joint Research Centre of PRO.MED.CS Praha a.s. and the Czech Academy of Sciences, Heyrovského 1207, 50002 Hradec Králové 2,

Czech Republic. e-mail:svoboda@uebf.cas.cz 